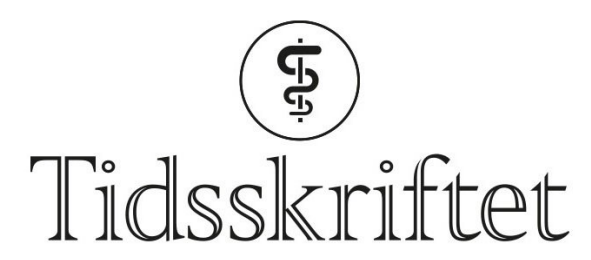

DEN NORSKE LEGEFORENING

\title{
Forside nr. 5/2021
}

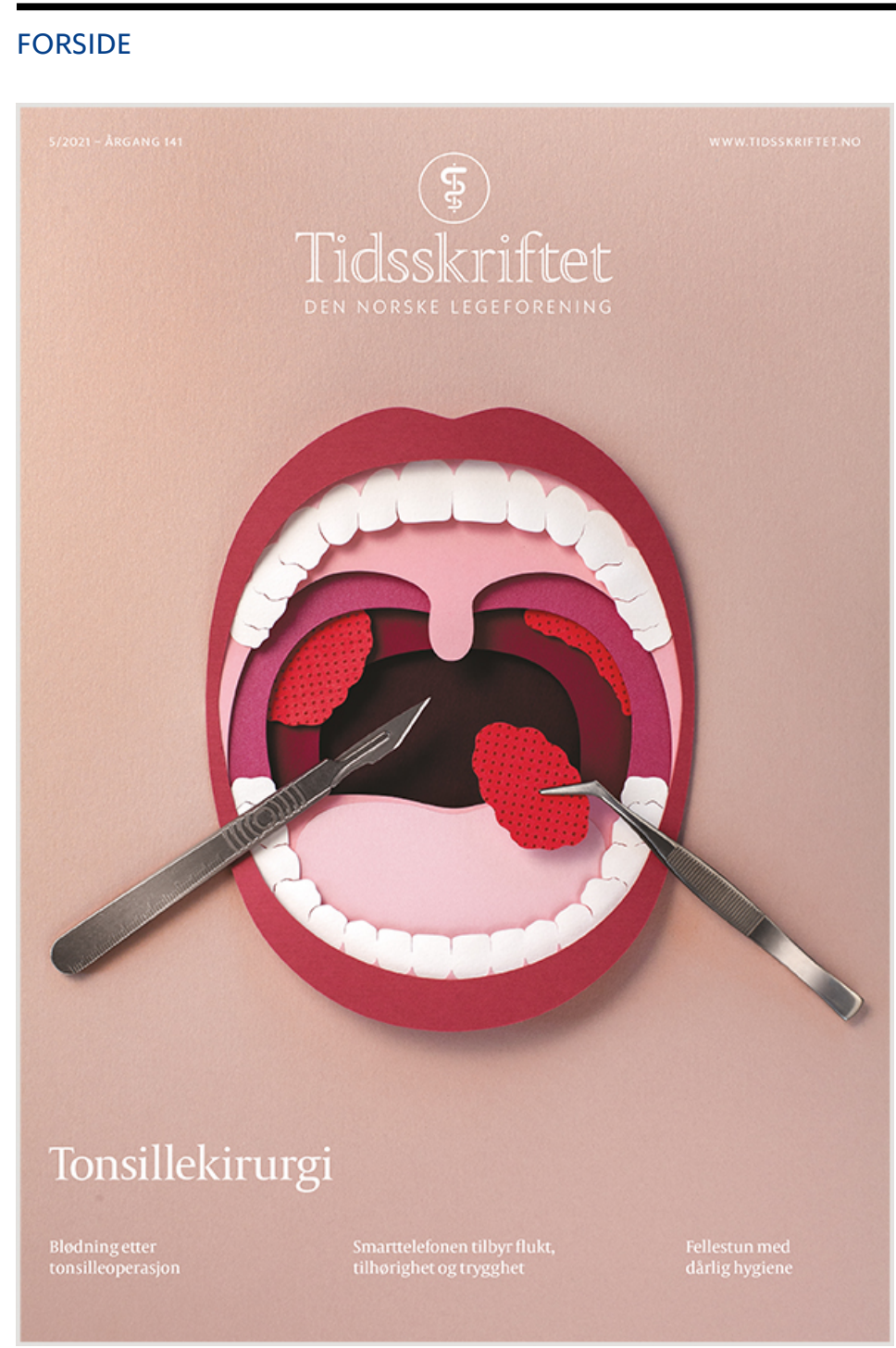

Illustrasjon @ Julie Wilkinson, Makerie Studio / ByHands

- Det er ikke hver dag jeg illustrerer tonsillektomier, men ettersom jeg har en forkjærlighet for gamle medisinske dokumenter og illustrasjoner, var det en drøm å få jobbe med Tidsskriftet, sier Julie Wilkinson, som har illustrert forsiden.

- Jeg har inkorporert instrumentene jeg bruker til papirutskjæring, en ekte skalpell og pinsett, i konseptualiseringen av en tonsillektomi. Dette var en enkel og ren måte å fremstille operasjonen, og det er første gang jeg har brukt instrumentene mine som del av et verk.

Flere av Wilkinsons arbeider kan du se her: www.makeriestudio.com 
Publisert: 22. mars 2021. Tidsskr Nor Legeforen. DOI: 10.4045/tidsskr.21.05.02 (C) Tidsskrift for Den norske legeforening 2020. Lastet ned fra tidsskriftet.no 